\title{
Intraspecific trait variability and genetic diversity in the adaptive strategies of serpentine and non-serpentine populations of Silene paradoxa $\mathrm{L}$.
}

\author{
Lorenzo Lazzaro (ID) - Ilaria Colzi (D) Daniele Ciampi • \\ Cristina Gonnelli $\cdot$ Lorenzo Lastrucci (i) Nadia \\ Bazihizina (1) - Daniele Viciani $(\mathbb{D}) \cdot$ Andrea Coppi $(\mathbb{D})$
}

Received: 21 April 2020 /Revised: 23 November 2020 / Accepted: 24 November 2020 / Published online: 3 December 2020

(C) The Author(s) 2020

\begin{abstract}
Aims We investigated whether individuals of Silene paradoxa L., grown in serpentine and non-serpentine soils, displayed variation in functional traits and adaptive strategies together with a differentiation of the gene pool. We hypothesised that individuals growing in serpentine sites may be exposed to a higher degree of stress, resulting in measurable differences in leaf traits and adaptive strategies, and as well that the differences in the soil type were associated with a genetic process of differentiation.

Methods We analysed a specific set of leaf functional traits of populations of S. paradoxa grown on serpentine and non-serpentine soils. Furthermore, DNAfingerprinting techniques were used to further dissect the emergence of genetic processes of differentiation linked to the different soil types.

Results We detected a relevant intraspecific trait variation in $S$. paradoxa, with the populations from serpentine sites significantly polarised towards the stresstolerant adaptive strategy. This polarisation came with a shift in gene pool selection, even if we did not detect
\end{abstract}

Responsible Editor: Juan Barcelo.

L. Lazzaro $(\bowtie) \cdot$ I. Colzi · D. Ciampi · C. Gonnelli •

N. Bazihizina $\cdot$ D. Viciani $\cdot$ A. Coppi

Department of Biology, University of Florence, Via G. La Pira, 4, Firenze 50121, Italy

e-mail: lorenzo.lazzaro@unifi.it

L. Lastrucci

Natural History Museum, Botany, University of Florence, Via G. La Pira, 4, 50121 Florence, Italy quantitative differences in the genetic diversity or evidence of genetic drift.

Conclusions The results indicate that particular edaphic conditions acted on the selection of some regions of the species' genome, independently of the site, with various portions of the genome being exclusive to or prevalent in the serpentine or non-serpentine populations.

Keywords AFLP · CSR strategy · Leaf traits - Genetic structure $\cdot$ Loci under selective pressure .

Serpentinophyte.

\section{Introduction}

Different environments in natural landscapes can exert divergent selection on plant species (Sakaguchi et al. 2017). In particular, the type of substrate (i.e. soil type) is one of the most important factors of ecological pressure, which is often pivotal in plant species diversification (Rajakaruna 2018). Indeed, plants found on extreme substrates are ideal systems for investigating the complex interactions between environment/edaphic factors and species at microevolutionary scales, disentangling the factors shaping genetic variation across a landscape (Bragg et al. 2015). Serpentine outcrops are chemically extreme substrate, extraordinarily challenging for plant life, and considered to be real "ecological islands" in a sea of normal soils (Lefèbvre and Vernet 1990). Worldwide distributed, they are characterised by high concentrations of trace elements (namely $\mathrm{Ni}, \mathrm{Co}$, and $\mathrm{Cr}$ ), along with other edaphic constraints, including high $\mathrm{Mg}$ 
concentration, low $\mathrm{Ca} / \mathrm{Mg}$ ratio, high $\mathrm{pH}$ values, and heat stress (Brooks 1987; Gonnelli and Renella 2012; Kazakou et al. 2008; Rajakaruna and Boyd 2009). Due to these characteristics, the spontaneous evolution and speciation of serpentinophytes have been frequently observed (see Rajakaruna 2018 and references therein). However, while on the one hand serpentine soils house several endemic strict metallophytes, on the other hand, they host (even more frequently) several species thriving on both metalliferous and non-metalliferous soils (Sianta and Kay 2019; Pollard et al. 2014; Harrison and Rajakaruna 2011). These facultative serpentinophytes may show a marked functional differentiation in serpentine ecotypes. For example, phenotypic differences have been observed between locally adapted serpentine and riparian populations of the serpentine Helianthus exilis A.Gray, with the serpentine population displaying smaller plants and leaves, bigger flower heads, and higher leaves nitrogen content (Sambatti and Rice 2007). These differences may be reflected in genetic (or more often multi-genetic) differentiation among serpentine and non-serpentine populations (Von Wettberg et al. 2014), as shown in the case of Arabidopsis lyrata (L.) O'Kane \& Al-Shehbaz, in which a large number of genetic differences were found between populations from serpentine and non-serpentine soils (Turner et al. 2010).

The genetic basis is fundamental in the selection of associated traits in extreme habitats (Bratteler et al. 2006; Burrell et al. 2012; Courbot et al. 2007; Deniau et al. 2006; Selby and Willis 2018; Willems et al. 2007). Thus, serpentine outcrops provide an excellent study system to explore the phenotypic plasticity of plants and understand whether the influence of environmental constraints on the genetic structure of a species may be related to variations of the observed functional traits. Moreover, while it has been proposed that the strong selective pressure and spatial isolation of serpentine soils might reduce the genetic diversity in serpentine populations (Nordal et al. 1999; Deng et al. 2007), several studies have so far shown that the opposite might also occur. Indeed, serpentine populations have also been found to have high genetic variation within populations, comparable or greater than that found in non-serpentine ones (Mengoni et al. 2000; QuintelaSabarís et al. 2010; Moore et al. 2013; Stojanova et al. 2020).

Silene paradoxa L. (Caryophyllaceae) provides an interesting model system to study the ecology and genetics of the adaptation to the serpentine habitats. It is widely distributed in southern Europe, presenting a large altitudinal amplitude, growing from the sea level up to $1300 \mathrm{~m}$ a.s.1. and colonising different types of soils, from siliceous to calcareous ones. It is a facultative serpentinophyte since it is generally found in noncontaminated dry areas (Pignatti 1997) but also shows several metallicolous populations on various kinds of metalliferous soils, such as serpentine outcrops (Selvi 2007) or mine tailings (Chiarucci et al. 1995). In previous studies focusing on their metal tolerance, several S. paradoxa populations from serpentine sites in central Italy have proved to be highly tolerant to $\mathrm{Ni}$, showing a metal excluder strategy (Arnetoli et al. 2008; Colzi et al. 2015; Gonnelli et al. 2001; Pignattelli et al. 2013; Martellini et al. 2014). Moreover, when looking at the genetic polymorphisms and phylogenetic relationships among different populations, random amplified polymorphic DNA and chloroplast microsatellite analyses have previously highlighted the lack of genetic divergence among serpentine and non-serpentine populations (Mengoni et al. 2000, 2001). Furthermore, Mengoni et al. (2001) proposed that the relatively high genetic diversity within serpentine populations found with both approaches may be linked to a reduced gene flow for S. paradoxa populations (especially considering their relatively low geographic distance). These views and findings fit with the ecological island model for serpentine outcrops and contaminated sites (Lefèbvre and Vernet 1990).

According to Grime's Competitive Stress-tolerant Ruderal (CSR) theory (Grime 1977; Grime and Pierce 2012), the selective pressures to which plants are subjected induce adaptive responses that follow three main directional lines. C-selected plants have developed highly competitive abilities, S-selected plants possess physiological peculiarities necessary to tolerate environmental stress and R-selected plants display characteristics necessary for the colonization of disturbed habitats. Such strategies are reflected in a number of different plant functional traits. Ranging from morphological, biochemical, physiological, structural, phenological to behavioural characteristics expressed in the phenotypes of an organism, they underpin both species role in ecosystem properties and services and their response to environmental stressors and disturbances (Violle et al. 2007; Suding et al. 2008). Recently, Pierce et al. (2017) showed that the position of individuals in the CSR framework can be reasonably deduced via the measurement of only three leaf functional traits: leaf 
area (LA), leaf dry matter content (LDMC), and specific leaf area (SLA), representing interspecific variation in plant size and conservative vs. acquisitive resource economics. It has long been observed that the Stress Resistance Syndrome is common to plants found in habitats characterised by water and nutrient limitations, the presence of toxins or edaphically toxic habitats (including serpentine soils), pollutants, or excesses of required nutrients (see Von Wettberg et al. 2014 and references therein). In these contexts, stress-tolerant plants tend to share a suite of traits, including low growth rates and tissue turnover coupled with slow rates of nutrient uptake and relatively highly-defended, carbon-rich tissue (Von Wettberg et al. 2014). SLA for instance is considered a key indicator of plant response to environmental conditions, decreasing in low-nutrient conditions and harsh climates, even if the actual variation of this trait may be linked to multiple non-independent environmental factors (Anacker et al. 2011). Moreover, particularly in Mediterranean serpentine settings, serpentine soils are considered a stressful growing environment for most plants due to their chemical (i.e. presence of excessive concentrations of trace elements) and physical properties (e.g., coarse texture, low accumulation of organic matter and low water-holding capacity, Sambatti and Rice 2007 and references therein).

In the present study, we determined whether individuals of $S$. paradoxa growing on serpentine and nonserpentine sites display significant differences in CSR adaptive strategies, identified through the measurement of LA, SLA and LDMC. In particular, we hypothesized that plants could display traits reflecting their position along a continuum where there is an increase in the magnitude of stress, with the species growing on serpentine soils being those displaying a higher degree of stress due to the peculiar features of these soils. We therefore expected serpentine populations to display a higher relative importance of the S strategy and related traits, e.g. lower SLA. Furthermore, despite the demonstrated absence of genetic divergence among serpentine and non-serpentine populations of $S$. paradoxa, we tested whether the populations growing on serpentine sites displayed specific DNA loci under selective pressure. Using a high-throughput, and high-resolution DNA-fingerprinting methodology we evaluated: (i) the genetic structure of $S$. paradoxa populations, particularly verifying the presence of differentiation in those grown on serpentine sites; and (ii) the relative contribution of genetic variation, in particular detecting DNA regions under selective pressure and their link with serpentine populations (thus reflecting potential adaptation to serpentine sites).

\section{Methods}

Sampling design and data collection

S. paradoxa is a perennial hemicryptophyte protandrous and self-compatible species. It has showy white flowers and is pollinated mainly by insects (Kruckeberg 1986). Both self- and cross-pollination can occur, and seeds are dispersed close to the mother plant by gravity and show a high germination rate (Kruckeberg 1986). To characterise the functional response of $S$. paradoxa, we sampled plants and soil material from 12 distinct populations from two different soil types: six serpentine sites and six nonserpentine ones (all in Tuscany, Central Italy, see Fig. 1). The geological substratum in non-serpentine sites varied from basalt to travertine and marl and sandstones (see table 1, data deduced from the geological map of Tuscany available at http://www502.regione.toscana. $\mathrm{it/geoscopio/geologia.html).} \mathrm{In} \mathrm{each} \mathrm{site,} \mathrm{we} \mathrm{collected}$ five soil samples to evaluate the elemental concentration of the selected trace elements $(\mathrm{Ca}, \mathrm{Mg}$ and $\mathrm{Ni}$ ). All sites represent the typical habitat of $S$. paradoxa and were mostly comparable concerning the vegetation structure, with a low shrub cover and a discontinuous herbaceous layer. These factors lead to a generally high solar radiation and to some degree of water stress. The area occupied by S. paradoxa populations within the sampling sites varied from 0.5 to 8 hectares, but all populations had a high number of individuals ( $>100$ individuals). The sampling for both genetic analyses and functional trait measurement included individuals in the main core of the population and excluded isolated individuals at its margins. The main information on the collection sites is summarised in Table 1.

To describe the adaptive strategy of $S$. paradoxa individuals, we measured a specific set of leaf traits, following the indications detailed in Perez-Harguindeguy et al. (2013). In each sampling site, we collected five leaves from each of ten different individuals. All the samplings took place in June 2018. Leaves were immediately immersed in cool deionised water and processed for the measurement within 24 hours from collection. We subsequently measured the following traits: (a) Leaf Fresh Weight (LFW); (b) LA, measured after digitizing the leaf 


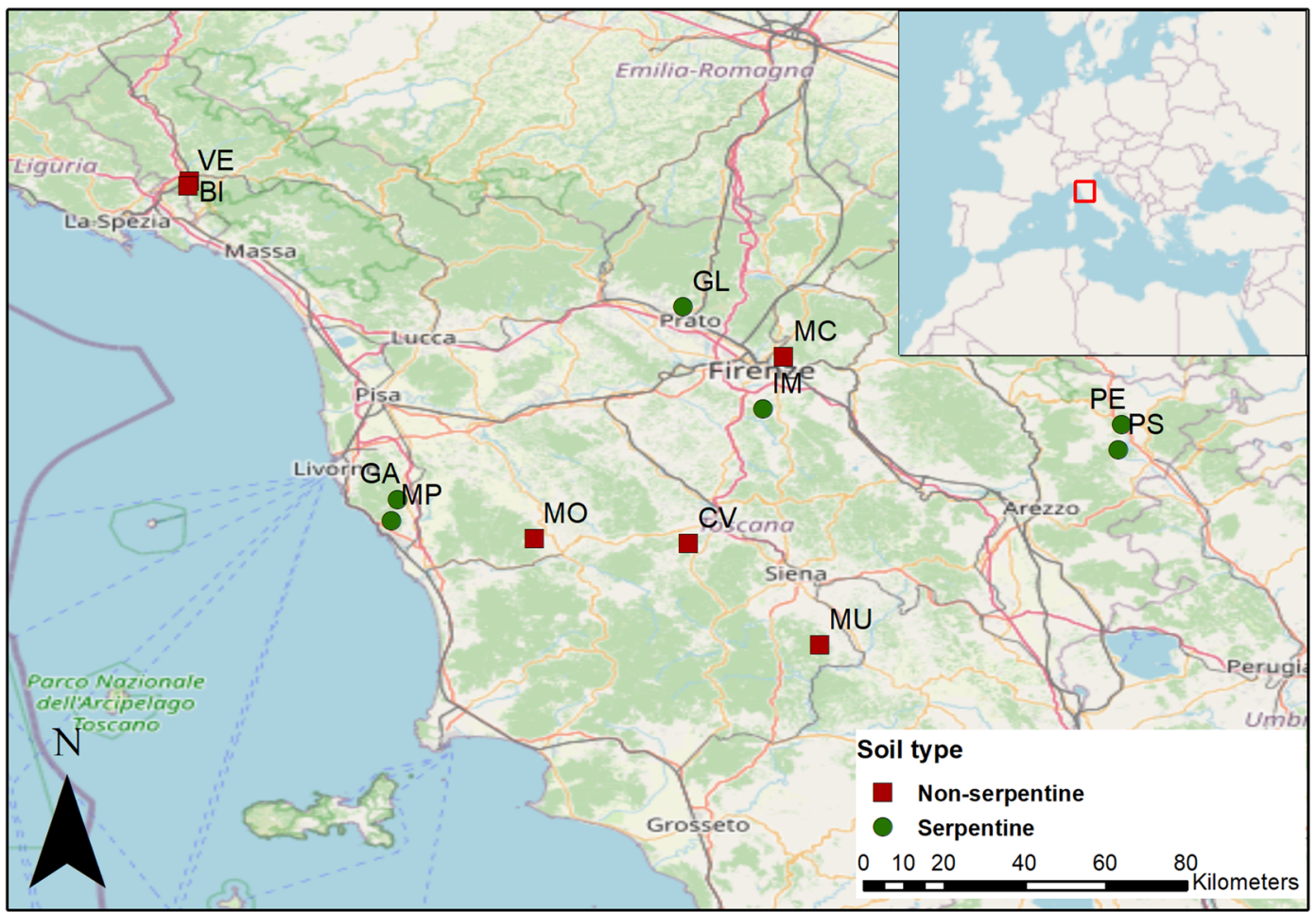

Fig. 1 Study area and location of the 12 sampling sites: $\mathrm{BI}=$ Bibola, Aulla; $\mathrm{CV}=$ Colle Val d'Elsa; $\mathrm{MU}=$ Murlo; $\mathrm{MC}=$ Monte Ceceri, Fiesole; $\mathrm{MO}=$ Montecatini Val di Cecina; $\mathrm{VE}=$ Vecchietto, Aulla; $\mathrm{GA}=$ Gabbro, Rosignano Marittimo; GL = Galceti, Prato; $\mathrm{IM}=$
Impruneta; $\mathrm{MP}=$ Monte Pelato, Rosignano Marittimo; $\mathrm{PE}=$ Monte Petroso; PS = Poggio degli Scopeti. Map layer contains data from OpenStreetMap (http://www.OpenStreetMap.org, () OpenStreetMap (and) contributors, CC-BY-SA)

Table 1 Information on the collection sites

\begin{tabular}{|c|c|c|c|c|c|c|c|c|}
\hline Soil type & Site & Full name of the site & $\begin{array}{l}\text { Geological } \\
\text { Substratum }\end{array}$ & $\begin{array}{l}\text { Extant } \\
\text { (ha) }\end{array}$ & $\mathrm{Ni}(\mu \mathrm{g} / \mathrm{g})$ & $\mathrm{Ca}(\mathrm{mg} / \mathrm{g})$ & $\mathrm{Mg}(\mathrm{mg} / \mathrm{g})$ & $\mathrm{Ca} / \mathrm{Mg}$ \\
\hline \multirow[t]{6}{*}{ Non-serpentine } & $\mathrm{BI}$ & Bibola, Aulla & Basalt & 2 & $153.3 \pm 3.4 \mathrm{a}$ & $13.6 \pm 0.6 \mathrm{a}$ & $24.9 \pm 1.5 \mathrm{a}$ & $0.55 \pm 0.04 \mathrm{a}$ \\
\hline & $\mathrm{CV}$ & Colle Val d'Elsa & $\begin{array}{l}\text { Calcareous } \\
\quad \text { (travertine) }\end{array}$ & 1 & $87.4 \pm 2.7 \mathrm{~b}$ & $103.7 \pm 4 \mathrm{~b}$ & $5.7 \pm 0.3 \mathrm{~b}$ & $18.5 \pm 1.4 \mathrm{~b}$ \\
\hline & MU & Murlo & Marl & 3 & $68.8 \pm 1 \mathrm{~b}$ & $8.3 \pm 0.4 \mathrm{c}$ & $11.4 \pm 0.1 \mathrm{~b}$ & $0.73 \pm 0.03 \mathrm{a}$ \\
\hline & $\mathrm{MC}$ & Monte Ceceri, Fiesole & $\begin{array}{l}\text { Marl and } \\
\text { sandstones }\end{array}$ & 0.5 & $69.8 \pm 1.6 \mathrm{~b}$ & $2.9 \pm 0.1 \mathrm{~d}$ & $9.7 \pm 0.2 \mathrm{~b}$ & $0.3 \pm 0.01 \mathrm{c}$ \\
\hline & $\mathrm{MO}$ & $\begin{array}{c}\text { Montecatini Val } \\
\text { di Cecina }\end{array}$ & Basalt & 0.5 & $84.3 \pm 3.0 \mathrm{~b}$ & $2.7 \pm 0.1 \mathrm{~d}$ & $9.7 \pm 0.2 \mathrm{~b}$ & $0.27 \pm 0.01 \mathrm{c}$ \\
\hline & VE & Vecchietto, Aulla & Basalt & 2 & $138.2 \pm 3.1 \mathrm{a}$ & $28 \pm 0.8 \mathrm{e}$ & $37.1 \pm 1.1 \mathrm{a}$ & $0.76 \pm 0.03 \mathrm{a}$ \\
\hline \multirow[t]{6}{*}{ Serpentine } & GA & $\begin{array}{l}\text { Gabbro, Rosignano } \\
\text { Marittimo }\end{array}$ & Serpentine & 0.5 & $1150.7 \pm 86.9 \mathrm{c}$ & $28.9 \pm 0.7 \mathrm{e}$ & $119.6 \pm 8.2 \mathrm{~cd}$ & $0.25 \pm 0.02 \mathrm{c}$ \\
\hline & GL & Galceti, Prato & Serpentine & 8 & $1683.5 \pm 12.2 \mathrm{~d}$ & $2 \pm 0.2 \mathrm{f}$ & $132.6 \pm 6.5 \mathrm{c}$ & $0.02 \pm 0 \mathrm{~d}$ \\
\hline & $\mathrm{IM}$ & Impruneta & Serpentine & 1 & $1639.5 \pm 47.9 \mathrm{~d}$ & $2.4 \pm 0.1 \mathrm{~d}$ & $135.3 \pm 5.9 \mathrm{c}$ & $0.02 \pm 0 \mathrm{~d}$ \\
\hline & $\mathrm{MP}$ & $\begin{array}{l}\text { Monte Pelato, Rosignano } \\
\text { Marittimo }\end{array}$ & Serpentine & 2 & $1724.7 \pm 17.9 \mathrm{~d}$ & $9.2 \pm 0.2 \mathrm{c}$ & $94.1 \pm 10.5 \mathrm{~d}$ & $0.10 \pm 0.01 \mathrm{e}$ \\
\hline & $\mathrm{PE}$ & Monte Petroso & Serpentine & 1 & $1671.6 \pm 68.1 \mathrm{~d}$ & $10.4 \pm 0.4 \mathrm{c}$ & $123.6 \pm 9.1 \mathrm{c}$ & $0.09 \pm 0.01 \mathrm{e}$ \\
\hline & PS & Poggio degli Scopeti & Serpentine & 2 & $1736.4 \pm 10 \mathrm{~d}$ & $6.7 \pm 0.2 \mathrm{~g}$ & $126.1 \pm 4.7 \mathrm{c}$ & $0.05 \pm 0.01 \mathrm{f}$ \\
\hline
\end{tabular}

Different letters indicate significant differences after a PostHOC Tukey test on soil concentrations of Nickel (Ni), Magnesium (Mg), Calcium $(\mathrm{Ca})$ and soil $\mathrm{Ca} / \mathrm{Mg}$ ratio. Extant $=$ Approximated surface occupied by population of Silene paradoxa in the site (ha $=$ hectares) 
outline (1200 dpi) using ImageJ v. 1.51 software (Schneider et al. 2012) and (c) Leaf Dry Weight (LDW), after $72 \mathrm{~h}$ at $70{ }^{\circ} \mathrm{C}$ in an oven. Leaves weight was measured with an analytical balance, accurate to $0.02 \mathrm{mg}$. For each leaf, we calculated the SLA according to the formula SLA $=\mathrm{LA} / \mathrm{LDW}$ and the LDMC according to the formula $\mathrm{LDMC}=\mathrm{LDW} / \mathrm{LFW}$. The values of the leaf traits were averaged by plant and we used the StrateFy analysis tool (Pierce et al. 2017) to calculate the relative contribution of CSR parameters for each individual according to Grime (1977) and Pierce et al. (2017). Additional leaves were collected from each sampled individual for chemical and genetic analyses.

Analyses of elements in soils and leaves

Since the excess of $\mathrm{Ni}$, together with the excess of $\mathrm{Mg}$ and a low $\mathrm{Ca} / \mathrm{Mg}$ ratio, is considered a remarkably unfavourable chemical characteristic of the serpentine factor (Brooks 1987; Gonnelli and Renella 2012), the concentrations of such elements were determined in soil and plant samples from all sampling sites. Soils were air-dried at room temperature for 7 days and then sieved to $2 \mathrm{~mm}$ with a stainless-steel mesh. After being driedup completely at $60^{\circ} \mathrm{C}$ in an oven, five aliquots of $0.5 \mathrm{~g}$ from each soil samples were weighted and used for the acid mineralisation through a microwave digestion system (Mars 6, CEM) as in Bettarini et al. (2019). Ten mL of $69 \% \mathrm{HNO}_{3}$ were added to the soil material and a cycle at $175^{\circ} \mathrm{C}$ for 20 minutes was used.

Leaf samples were carefully washed with deionised water and oven-dried at $70{ }^{\circ} \mathrm{C}$ for $24 \mathrm{~h}$. Leaves collected from the same plant individual were pooled together, grounded with mortar and pestle, and homogenised. Aliquots of $0.05 \mathrm{~g}$ dried material were mineralised through a microwave oven as described above for soils $\left(200{ }^{\circ} \mathrm{C}\right.$ for $20 \mathrm{~min}$ ). After mineralization, total element concentration in both soil and plant samples was determined by flame atomic absorption spectrometry (AAnalyst 200, Perkin Elmer) as in Bettarini et al. (2019).

\section{Genetic analyses}

Individual leaf samples collected during the field campaign were dried on silica-gel and subsequently ground in a mortar with sterile sand to be subjected to genetic analyses. The DNA was extracted by using the $2 \mathrm{xCTAB}$ protocol (Doyle and Doyle 1990). The extracted DNA was quantified by a Bio-Photometer (Eppendorf). An analysis of divergence at Amplified Fragment Length Polymorphism (AFLP) was performed following the standard procedure in Vos et al. (1995), but with minor changes as described in Coppi et al. (2014 and references therein). The appealing of AFLP approach consists in the increasing ease (low cost and low time consuming) of generating a large number of analysable markers, and the possibility to identify a number of DNA regions showing an unusual pattern of variation, thus potentially under selective pressure. After a preliminary test on the reproducibility of the AFLP protocol (Coppi et al. 2018), one combination of primers was selected for the final analysis: hex_EcoRI-CTA/MseIATG and fam_EcoRI-TAC/MseI-ATG. Analysis of the AFLP profiles obtained by capillary electrophoresis was performed with GeneMarker v1.5 (SoftGenetics LLC, PA USA). A cut-off value was fixed at $5 \%$ of the maximum fluorescence peak observed.

We evaluated the presence/abundance of outlier loci to identify regions of the genome under natural selection, using differences in loci frequencies between populations (Beaumont and Nicholas 1996; Beaumont and Balding 2004). This method assumes that the locus frequencies within a population follow a multivariate $\beta$-distribution as a function of the multilocus Fixation Index value and the average of locus frequencies of each locus between populations (Burr 2000; Rannala 1996; Rannala and Hartigan 1996). The BayeScan analysis was carried out following Yang et al. (2016). The number of pilot runs was kept at 20, with a length of 10000 iterations each one (Coppi et al. 2018). We then calculated the within-population average genetic diversity (He hereafter) using the program Arlequin v2.000 (Schneider et al. 2000) and following the Nei's metrics (Nei 1987). The $\mathrm{He}$ values were calculated for the total of the AFLP loci detected (He_all), and then separately for the outlier loci (He_out).

\section{Data analyses}

We analysed the ion concentration among soils from the different collection sites at two levels. First, to describe the chemical features of the collection sites, we used a one-way parametric ANOVA coupled with a Tukey's PostHOC comparison with ion concentration as the response variable and collection site as the explanatory variable. As a second analysis, to assess the differences among soil types (i.e. serpentine vs. non-serpentine 
ones), we set a series of nested ANOVAs via linear mixed models (LMMs) evaluating the differences in ion concentration. In the LMMs we used soil type as the fixed effect term and the collection site as the random effect term nested in the soil type. The significance of the fixed effect was evaluated by means of a type III ANOVA table with Satterthwaite approximation for degrees of freedom. As a measure of goodness of fit in the analysis and of the importance of the random effect factor, we calculated two different pseudo R-squared $\left(\mathrm{R}^{2}\right)$ measures according to the Nakagawa and Schielzeth (2013) definition. We calculated the marginal $\mathrm{R}^{2}$ describing the proportion of variance explained by the fixed factors alone, and the conditional $\mathrm{R}^{2}$ describing the proportion of variance explained by both fixed and random factors.

To evaluate the role of each soil type in defining the functional response of the individuals, we run again a series of nested ANOVAs via LMMs evaluating the differences in leaf trait values (i.e. LA; LFW; LDW; LDMC; SLA) and in each component in the CSR diagram. Here, to avoid autocorrelation of individuals from the same population, we used the soil type as the fixed effect term and the population of origin as random effect term nested in the soil type. Similarly, we used LLMs to examine ion accumulation of $\mathrm{Ni}, \mathrm{Ca}, \mathrm{Mg}$ and the $\mathrm{Ca} / \mathrm{Mg}$ ratio in shoot tissues in individuals from different soil type; also in this case we used the soil type as the fixed effect term and the population of origin as the random effect term nested in the soil type. In LMMs, response variables were transformed adopting the one-parameter Box-Cox transformation (Box and Cox 1964) to achieve normality of residuals and the significance of the fixed effect was evaluated by means of an ANOVA table with Satterthwaite approximation for degrees of freedom. Again we calculated the marginal and the conditional $\mathrm{R}^{2}$ as described above.

We run a Principal Component Analysis (PCA) using the main leaf trait values (i.e. LA; LDMC; SLA) and concentrations of $\mathrm{Ni}, \mathrm{Ca}, \mathrm{Mg}$ and the $\mathrm{Ca} / \mathrm{Mg}$ ratio in individuals as response variables to evaluate the position of these individuals in the ordination diagram, and verify how individuals from different soil type segregate in the ordination space.

To evaluate the structure of $S$. paradoxa populations, we performed an analysis of molecular variance (AMOVA, Excoffier et al. 1992), implemented in Arlequin v2.000 (Schneider et al. 2000). This was used to analyse the partition of the genetic variation within and among populations, as well as grouping the populations on the base of the soil type. Genetic distances among populations were estimated by computing a matrix of pairwise Fst values (Slatkin 1995). The neighbour-joining dendrogram (Saitou and Nei 1987) was then used to represent the levels of genetic differentiation among populations. Moreover, to verify the presence of a correlation between genetic distance expressed by Fst values and geographic distance among the populations, these were compared using a Mantel's randomization test (according to Manly 1986). Mantel's test may provide simple and useful tools for multivariate analysis of spatial patterns of genetic divergence (DinizFilho et al. 2013). Genetic structure among populations was also investigated using the STRUCTURE software version 2.3.3 (Pritchard et al. 2000). Admixture models were adopted with a burn-in period of 10,000 steps followed by 500,000 Monte Carlo Markov Chain replicates. The optimal value of $\mathrm{K}$ was assigned using the AveDissR function, as described by Yang and $\mathrm{Fu}$ (2017).

The differences in the total number of polymorphic loci between populations were measured with a nonparametric Kruskal test due to the non-normality of residuals. These differences were then used to determine the genetic diversity among populations from different soil types. The differences in $\mathrm{He}$ _all and $\mathrm{He}$ _out were assessed with a one-way ANOVA. We further inspected these differences at the individual level by identifying patterns of variation in both the number of total and outlier loci, again with a nested ANOVAs via LMMs, specifying the population of origin as a random effect factor nested in soil type. The significance of the fixed effect was evaluated by means of an ANOVA table with Satterthwaite approximation for degrees of freedom and we calculated the marginal and the conditional $\mathrm{R}^{2}$ as described above.

The variation in the distribution of both total and outlier loci in individuals according to the different soil types was analysed by means of a Canonical Correspondence Analysis (CCA), using the presence/absence of loci in each individual as response variables and the soil type as explanatory variable. The significance of the effect of the soil type was evaluated using a test on the constrained axis with 4999 permutations. Furthermore, to assess the specificity of loci to one of the soil types, we carried out an Indicator Species Analysis (ISA, Dufrêne and Legendre 1997). The ISA enables us to compute an indicator value $d$ (ranging between 0 and 
100 ) for each locus as the product of the relative frequency and relative average abundance of loci in clusters. The significance of $d$ is considered as the probability of obtaining a value as high as that observed over 1000 iterations.

All analyses were carried out in $\mathrm{R}$ version 4.0.3 (https://www.R-project.org). LMMs were performed using the 'Ime4' package version 1.1-20 (Bates et al. 2015) and the significance of the fixed effects was evaluated using the 'ImerTest' package version 3.0-1 (Kuznetsova et al. 2017). Marginal and conditional $\mathrm{R}^{2}$ of LMMs were calculated using the "piecewiseSEM" package version 2.1.0 (Lefcheck 2016). Tukey's PostHOC comparisons on soils were done using the 'multcomp' package version 1.4-8 (Hothorn et al. 2008), and all graphs were drawn using 'ggplot2' version 3.1.0 (Wickham 2016) and 'ggtern' version 3.1.0 (Hamilton and Ferry 2018). All multivariate analyses and relative graphs were made using Canoco 5 for Windows (version 5.10; Ter Braak and Smilauer 2012).

\section{Results}

Element concentration in soils and plants

Serpentine soils showed significantly higher mean concentrations of $\mathrm{Ni}\left(1601 \pm 91\right.$ vs. $\left.100 \pm 15 \mu \mathrm{g} \mathrm{g}^{-1}\right)$ and $\mathrm{Mg}\left(122 \pm 6\right.$ vs. $\left.16 \pm 5 \mathrm{mg} \mathrm{g}^{-1}\right)$ compared to nonserpentine ones (see Table 2). Although generally lower values were measured in serpentine $(9.9 \pm 4.0 \mathrm{mg} / \mathrm{g})$ than in non-serpentine soils $(26.5 \pm 15.9 \mathrm{mg} / \mathrm{g})$, the total mean $\mathrm{Ca}$ concentration was not significantly different between the two soil types (Table 2), probably due to a very high variability within the non-serpentine sites (particularly coming from very high $\mathrm{Ca}$ concentration in Colle Val d'Elsa, due to the calcareous parent material of this site). The mean $\mathrm{Ca} / \mathrm{Mg}$ ratio was however significantly lower in serpentine soils $(0.1 \pm 0.03$ vs. 3.5 \pm 3.0 ) compared to non-serpentine ones (Table 2). Some differences in the concentrations of the analysed metals were also found within similar soil types (see Table 1 for site values and Table 2 for results of statistical analyses at site level). Regarding element concentrations in shoots, the serpentine plants showed a significantly higher concentration only in the case of $\mathrm{Mg}$ (P value < 0.001 , Table 2). No significant differences were recorded for $\mathrm{Ni}, \mathrm{Ca}$ and $\mathrm{Ca} / \mathrm{Mg}$ ratio.

\section{Leaf traits}

As to leaf traits, LA, LFW and SLA were significantly different among populations occurring on different soil types ( $\mathrm{P}$ value $<0.05$, Table 3 ), while LDMC differed only slightly (difference only partially significant, $\mathrm{P}$ value $<0.1$, Table 3). Plants from serpentine sites had smaller leaves, thus also showing a smaller LFW, but a slightly higher LDMC. In addition, SLA was significantly lower in plants from serpentine sites. The differences in these leaf traits are reflected in differences in the relative components of the CSR diagram (all differences significant at $\mathrm{P}$ value $<0.05$, Table 3 ). Individuals from serpentine sites resulted more polarised toward the $\mathrm{S}$ component, at the expense of the other two components (see Fig. 2a and b), whereas individuals from nonserpentine sites showed a higher contribution of the $\mathrm{C}$ and $\mathrm{R}$ components.

Table 2 Result of the comparisons of elements contents in soils at the site and soil type (i.e. non-serpentine and serpentine sites) level

\begin{tabular}{|c|c|c|c|c|c|c|c|c|c|}
\hline VARIABLES & & $\lambda$ & Sum Sq & Df & Fvalue & $P$ value & & Marginal $\mathrm{R}^{2}$ & Conditional $\mathrm{R}^{2}$ \\
\hline \multirow[t]{4}{*}{ Site levele } & $\mathrm{Ni}$ & 0.262 & 2839.86 & 11,47 & 1609.24 & $<0.001$ & $* * *$ & - & - \\
\hline & $\mathrm{Ca}$ & -0.182 & 31.49 & 11,47 & 589.07 & $<0.001$ & $* * *$ & - & - \\
\hline & $\mathrm{Mg}$ & 0.586 & 6245.01 & 11,47 & 179.73 & $<0.001$ & $* * *$ & - & - \\
\hline & $\mathrm{Ca} / \mathrm{Mg}$ & -0.141 & 269.86 & 11,47 & 444.26 & $<0.001$ & $* * *$ & - & - \\
\hline \multirow[t]{4}{*}{ Soil type level } & $\mathrm{Ni}$ & 0.3 & 123.58 & $1,10.01$ & 457 & $<0.001$ & $* * *$ & 0.97 & 1 \\
\hline & $\mathrm{Ca}$ & -0.2 & 0.01 & 1,10 & 0.53 & 0.484 & & 0.04 & 0.99 \\
\hline & $\mathrm{Mg}$ & 0.6 & 507.25 & $1,9.98$ & 140.71 & $<0.001$ & $* * *$ & 0.90 & 0.97 \\
\hline & $\mathrm{Ca} / \mathrm{Mg}$ & -0.1 & 0.65 & $1,9.99$ & 14.82 & 0.003 & $* *$ & 0.55 & 0.99 \\
\hline
\end{tabular}

Marginal and Conditional $\mathrm{R}^{2}$ are provide in case of linear mixed models. $\lambda=$ lambda value adopted in power Box-Cox transformation of the

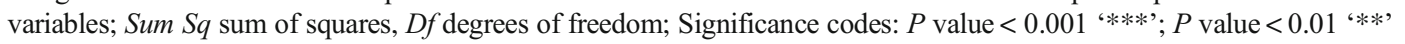


Table 3 Result of the comparisons of leaf traits, CSR relative component and chemical element concentrations across individuals from nonserpentine and serpentine sites

\begin{tabular}{|c|c|c|c|c|c|c|c|c|c|c|c|}
\hline VARIABLES & & $\begin{array}{l}\text { Non- } \\
\text { serpentine }\end{array}$ & Serpentine & $\lambda$ & Sum Sq & Df & Fvalue & $P$ value & & $\begin{array}{l}\text { Marginal } \\
\mathrm{R}^{2}\end{array}$ & $\begin{array}{l}\text { Conditional } \\
\mathrm{R}^{2}\end{array}$ \\
\hline \multirow[t]{5}{*}{ Leaf traits } & $\mathrm{LA}\left(\mathrm{mm}^{2}\right)$ & $\begin{array}{l}171.7 \pm 7.6 \\
(0.32)\end{array}$ & $\begin{array}{l}122.5 \pm 5.9 \\
(0.37)\end{array}$ & 0.465 & 134.78 & 1,10 & 12.02 & 0.006 & $* *$ & 0.178 & 0.282 \\
\hline & LFW (mg) & $\begin{array}{l}53.9 \pm 2.7 \\
(0.37)\end{array}$ & $\begin{array}{l}41.4 \pm 2.2 \\
(0.40)\end{array}$ & 0.343 & 11.67 & 1,10 & 6.147 & 0.033 & $*$ & 0.097 & 0.205 \\
\hline & LDW (mg) & $\begin{array}{l}12.7 \pm 0.7 \\
(0.38)\end{array}$ & $\begin{array}{l}10.5 \pm 0.5 \\
(0.37)\end{array}$ & 0.343 & 1.62 & 1,10 & 2.53 & 0.143 & & 0.054 & 0.231 \\
\hline & LDMC (\%) & $\begin{array}{l}23.6 \pm 0.4 \\
(0.12)\end{array}$ & $\begin{array}{l}25.76 \pm 0.4 \\
(0.11)\end{array}$ & 1.071 & 30.26 & 1,10 & 3.355 & 0.097 & & 0.1 & 0.393 \\
\hline & SLA $\left(\mathrm{mm}^{2} / \mathrm{mg}\right)$ & $\begin{array}{l}14.1 \pm 0.4 \\
(0.22)\end{array}$ & $\begin{array}{l}11.8 \pm 0.3 \\
(0.19)\end{array}$ & -0.788 & $<0.01$ & 1,10 & 6.663 & 0.027 & $*$ & 0.167 & 0.406 \\
\hline \multirow[t]{3}{*}{$\begin{array}{l}\text { CSR relative } \\
\text { component }\end{array}$} & $\mathrm{C}(\%)$ & $\begin{array}{l}14.5 \pm 0.6 \\
(0.32)\end{array}$ & $\begin{array}{l}11.0 \pm 0.5 \\
(0.38)\end{array}$ & 0.667 & 29.40 & 1,10 & 9.019 & 0.013 & $*$ & 0.127 & 0.216 \\
\hline & $\mathrm{S}(\%)$ & $\begin{array}{l}56.6 \pm 2.4 \\
(0.31)\end{array}$ & $\begin{array}{l}74.0 \pm 1.9 \\
(0.19)\end{array}$ & 1.636 & 241723.80 & 1,10 & 8.023 & 0.018 & $*$ & 0.214 & 0.478 \\
\hline & $\mathrm{R}(\%)$ & $\begin{array}{l}28.8 \pm 2.2 \\
(0.56)\end{array}$ & $\begin{array}{l}15.0 \pm 1.7 \\
(0.87)\end{array}$ & 0.505 & 49.55 & 1,10 & 6.524 & 0.029 & $*$ & 0.177 & 0.445 \\
\hline \multirow{4}{*}{$\begin{array}{l}\text { Content of } \\
\text { chemical } \\
\text { elements in } \\
\text { leaves }\end{array}$} & $\mathrm{Ni}(\mu \mathrm{g} / \mathrm{g})$ & $\begin{array}{l}10.1 \pm 0.9 \\
(0.69)\end{array}$ & $\begin{array}{l}12.1 \pm 0.9 \\
(0.6)\end{array}$ & 0.343 & 2.54 & 1,10 & 1.504 & 0.249 & & 0.042 & 0.295 \\
\hline & $\mathrm{Ca}(\mu \mathrm{g} / \mathrm{g})$ & $\begin{array}{l}7143 \pm 522 \\
(0.53)\end{array}$ & $\begin{array}{l}8189 \pm 483 \\
(0.45)\end{array}$ & 0.667 & 8472.50 & 1,10 & 0.379 & 0.552 & & 0.015 & 0.421 \\
\hline & $\mathrm{Mg}(\mu \mathrm{g} / \mathrm{g})$ & $\begin{array}{l}3420 \pm 133 \\
(0.28)\end{array}$ & $\begin{array}{l}5420 \pm 221 \\
(0.31)\end{array}$ & 0.020 & 2.69 & 1,10 & 24.662 & $<0.001$ & $* * *$ & 0.345 & 0.455 \\
\hline & $\mathrm{Ca} / \mathrm{Mg}$ & $\begin{array}{l}2.1 \pm 0.1 \\
(0.44)\end{array}$ & $\begin{array}{l}1.5 \pm 0.1 \\
(0.35)\end{array}$ & 0.788 & 0.73 & 1,10 & 3.175 & 0.105 & & 0.129 & 0.569 \\
\hline
\end{tabular}

Mean values \pm Standard Errors are given, while the coefficient of variation of the mean $(\mathrm{CV})$ is indicated in round brackets. $\lambda=$ lambda value adopted in power Box-Cox transformation of the variables; Sum $S q$ sum of squares, $D f$ degrees of freedom; Significance codes: $P$ value $<$ 0.001 '***'; $P$ value $<0.01$ '**'; $P$ value $<0.05^{\text {'* }}$ '

Individuals from different soil types appeared well segregated according to the PCA first axis (Fig. 3, total variation 777.0, variation explained by $\mathrm{PC} 1=37.7 \%$, variation explained by $\mathrm{PC} 2=20.5 \%$ ). Particularly, axis PC1 was highly positively correlated to SLA (increasing in individuals from non-serpentine sites) and negatively correlated to LDMC, Mg and Ni (increasing in individuals from serpentine sites). On the other hand, axis PC2 expressed a further differentiation, mostly independent from the soil type, positively correlated to the $\mathrm{Ca} / \mathrm{Mg}$ ratio and, to a lesser extent, to $\mathrm{Ca}$.

Genetic analyses

The AFLP analysis produced reliable results for 118 samples. The selected combinations of primers highlighted 236 total loci, with a percentage of polymorphic loci ranging from a maximum of 72.9 for $\mathrm{BI}$, to a minimum of 47.5 for PE. The analysis of the partition of genetic variation, within and among populations, showed that most of the variance was due to within- population differences $(74.13 \%$ of the total variation, $\mathrm{P}$ value $<0.001$ ) rather than among population differences ( $25.87 \%$ of total variation, $\mathrm{P}$ value $<0.001$ ). The partition of variance remained unvaried also when grouping the populations on the base of the soil types (data not shown).

The reconstruction of the genetic relationships among the populations did not support any particular structure toward a clustering of populations from serpentine sites. Indeed, even though genetic distances among populations were mostly significant $(\mathrm{P}$ value $<$ 0.05 according to a pairwise distance test with 1023 permutations, except from IM and GL), serpentine populations did not form a separate group in the NeighbourJoining (Fig. 4). Moreover, the Mantel test did not highlight a significant correlation between genetic and geographical distances between populations ( $\mathrm{P}$ value $>$ 0.05). The analysis of genetic distinctness with AveDissR allowed identifying three different genetic groups $(\mathrm{K}=3)$. The clustering with STRUCTURE showed that the populations are largely homogeneous, 


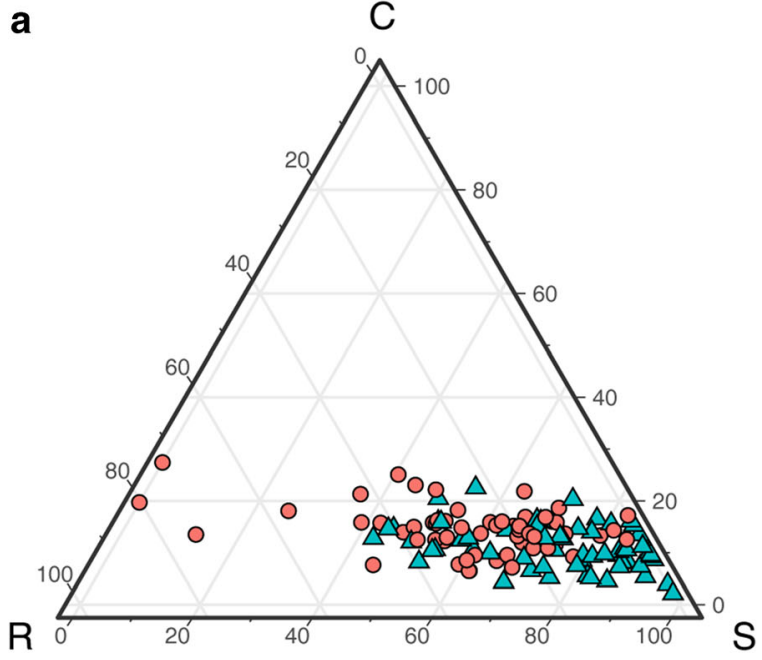

b

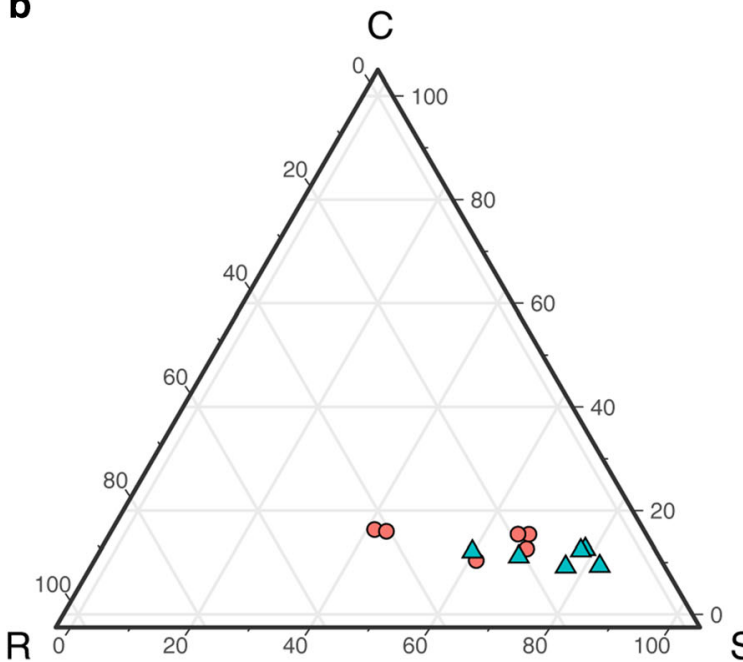

Fig. 2 Ternary CSR plot of individuals of Silene paradoxa grown on serpentine (blue tringles) and non-serpentine sites (pink circles). In (a) single individuals are shown, while in (b) they are pooled by population of origin. $\mathrm{C}=$ Competitive; $\mathrm{S}=$ Stress tolerant; $\mathrm{R}=$ Ruderal

with the predominance of one or two gene pools. The only exception was for BI, in which all of three gene pools were well represented (Fig. 5).

The outlier analysis identified eight loci that had a posteriori probability greater than 0.76 (at a threshold of $\log 10 \mathrm{PO}>0.5$ ), representing $3.4 \%$ of all loci. The higher mean number of outliers per individual was 6.2 for GA, whereas the lowest was 0.4 for MC. Nevertheless, the total number of loci detected, He_all (mean value 0.209 ) and He_out (0.188), were comparable among populations from different soil types (Table 4).

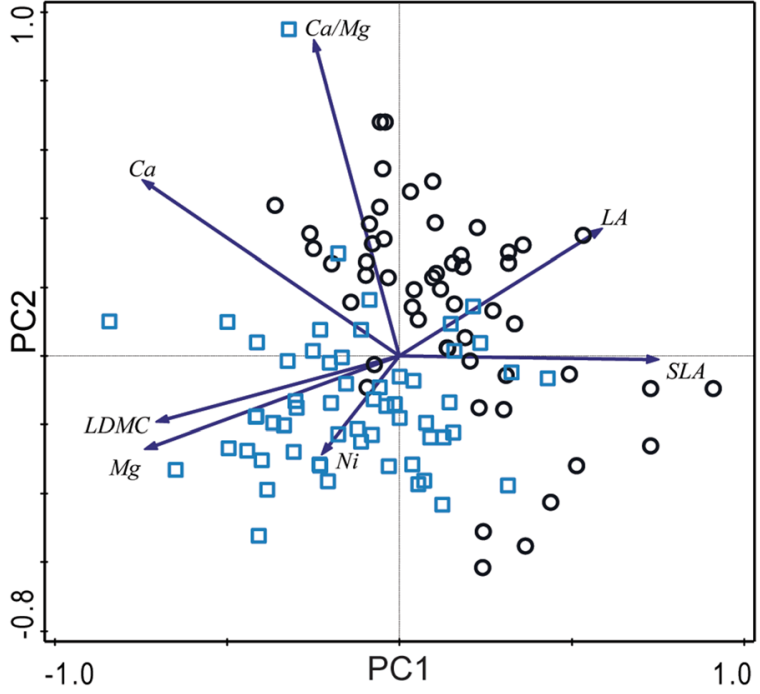

Fig. 3 Ordination plot of individuals of Silene paradoxa grown on serpentine (blue squares) and non-serpentine sites (black circles) based on Principal Component Analysis with leaf trait values (i.e. $\mathrm{LA}=\mathrm{Leaf}$ area; $\mathrm{LDMC}=$ Leaf dry matter content; SLA = Specific leaf area) and concentrations of $\mathrm{Ni}, \mathrm{Ca}, \mathrm{Mg}$ and $\mathrm{Ca} / \mathrm{Mg}$ ratio in individuals as response variables

No significant differences were detected in the mean number of total loci and outlier loci among individuals from different soil types (Table 4).

Notwithstanding the lack of quantitative differences, both the CCA and the ISA highlighted the presence of qualitative differences in the distribution of total and outlier loci in relation to the soil type (Fig. 6a and b). The ISA individuated a higher number of both total and outlier loci significantly specific to populations from serpentine sites (i.e. 85 loci and 4 outlier loci specific to serpentine sites vs. only 4 loci and 1 outlier locus specific to non-serpentine sites).

\section{Discussion}

Serpentine soils are characterised by high Ni concentrations and a low $\mathrm{Ca} / \mathrm{Mg}$ ratio (Brooks 1987), as also highlighted by our chemical analyses. Nevertheless, despite the contrasting chemical properties of serpentine and non-serpentine soils, $S$. paradoxa populations collected from the different sites showed similar $\mathrm{Ni}$ and $\mathrm{Ca}$ concentrations and $\mathrm{Ca} / \mathrm{Mg}$ ratio in shoot tissues. Thus, both $\mathrm{Ni}$ exclusion and $\mathrm{Ca}$ accumulation are likely to account for several adaptation mechanisms evolved by the serpentine populations of $S$. paradoxa. In particular, the latter mechanism is a well-known strategy used to 
Fig. 4 Neighbour-Joining dendrogram of serpentine and non-serpentine populations based on pairwise FST distances

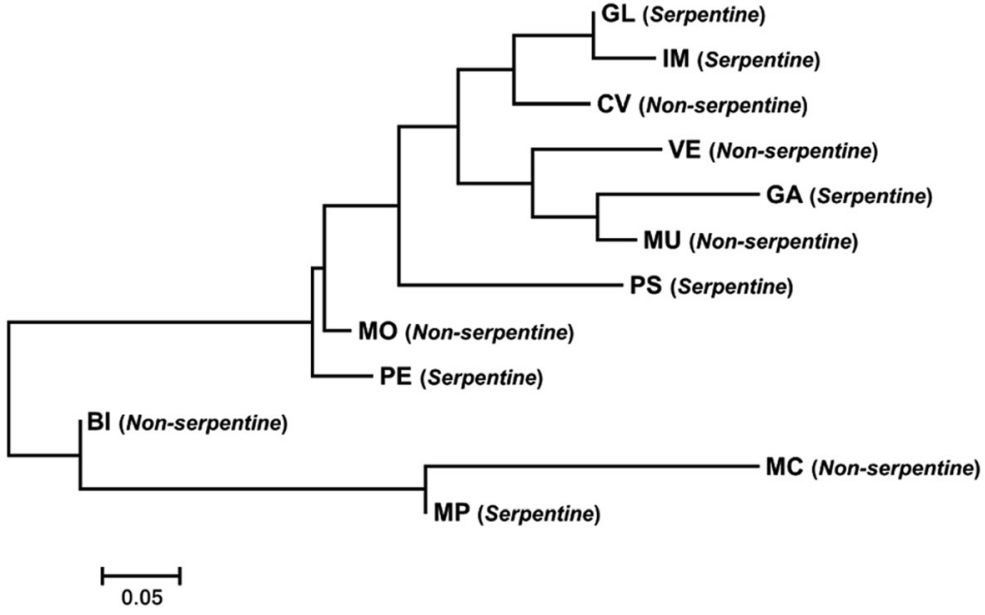

maintain adequate internal concentrations of $\mathrm{Ca}$ at the low $\mathrm{Ca} / \mathrm{Mg}$ ratios typical of serpentine soils (Wallace et al. 1982; Tibbetts and Smith 1993; Asemaneh et al. 2007, Ghasemi et al. 2015). In the serpentine populations of $S$. paradoxa, the great $\mathrm{Ca}$ acquisition was responsible for the reversal of the $\mathrm{Ca} / \mathrm{Mg}$ ratio in the plant tissue compared with the soil, which is a trait already found in other serpentinophytes (Bettarini et al. 2019; Mengoni et al. 2006). As for $\mathrm{Mg}$, despite its elevated concentration in soils, also this element appeared to be excluded by the individuals from the serpentine outcrops. The exclusion of $\mathrm{Mg}$, together with $\mathrm{Ca}$ accumulation, is consideredas a possible physiological mechanism of serpentine-adapted plants to cope with the low soil $\mathrm{Ca} / \mathrm{Mg}$ (Madhok and Walker 1969; Sambatti and Rice 2007). Indeed, although shoot Mg concentrations were higher than in the non-serpentine populations, values in serpentine populations remained within the optimal range for plants (Marschner 1995). These results highlight how in Ni-excluding plants, such as $S$. paradoxa, the measurement of trace metals in shoots may be a biased trait, insufficient alone to evaluate the possible correlation between the chemical characteristics of the soil and the plant ionome, and should
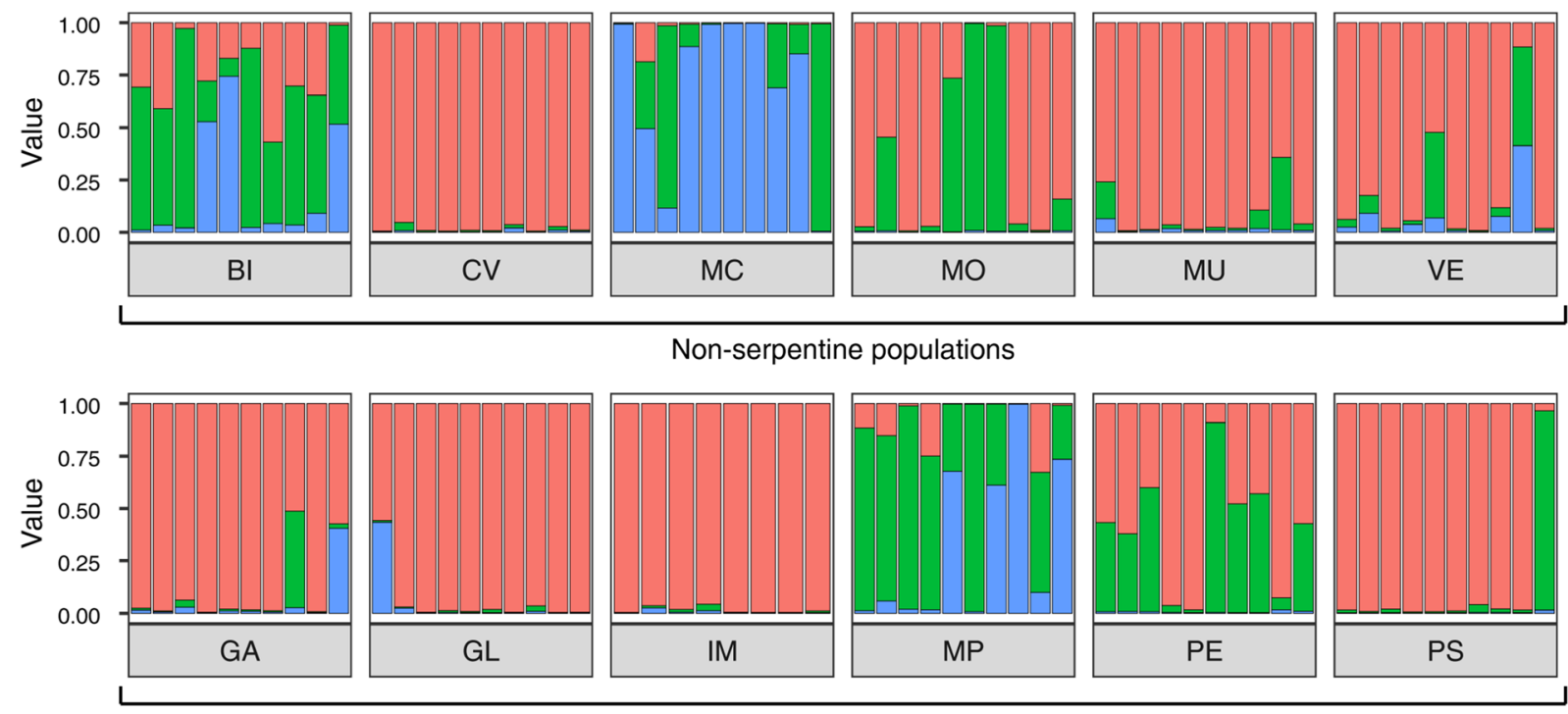

Non-serpentine populations
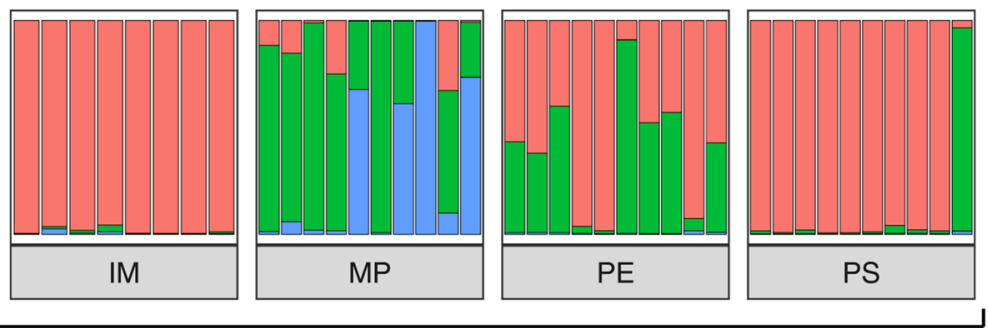

Serpentine populations

Gene pools:

K1

$\mathrm{K} 2$ K3

Fig. 5 Genetic structure of $S$. paradoxa populations resulting from the model-based clustering performed by STRUCTURE, with K=3 
Table 4 Result of the comparisons of genetic diversity among populations and individuals from non-serpentine and serpentine sites

\begin{tabular}{|c|c|c|c|c|c|c|c|c|c|}
\hline VARIABLES & & $\begin{array}{l}\text { Non- } \\
\text { serpentine }\end{array}$ & Serpentine & Stat. & Value & Df & $P$ value & $\begin{array}{l}\text { Marginal } \\
\mathrm{R}^{2}\end{array}$ & $\begin{array}{l}\text { Conditional } \\
\mathrm{R}^{2}\end{array}$ \\
\hline \multirow[t]{3}{*}{ POP levele } & Total number of loci & $137.7 \pm 7.2$ & $130.3 \pm 8.9$ & $\begin{array}{l}\text { Kruskal-Wallis } \\
\chi^{2}\end{array}$ & 1.641 & 1 & 0.200 & - & - \\
\hline & He_all & $0.21 \pm 0.01$ & $0.20 \pm 0.01$ & F value & 0.546 & 1,10 & 0.477 & - & - \\
\hline & He_out & $0.21 \pm 0.03$ & $0.16 \pm 0.03$ & $\mathrm{~F}$ value & 1.002 & 1,10 & 0.340 & - & - \\
\hline \multirow{2}{*}{$\begin{array}{l}\text { Individual } \\
\text { level }\end{array}$} & Number of total loci & $108.8 \pm 4.1$ & $120.4 \pm 3.3$ & Fvalue & 0.646 & 1,10 & 0.440 & 0.039 & 0.731 \\
\hline & $\begin{array}{l}\text { Number of outlier } \\
\text { loci }\end{array}$ & $3.4 \pm 0.3$ & $3.9 \pm 0.3$ & Fvalue & 0.199 & 1,10 & 0.665 & 0.013 & 0.785 \\
\hline
\end{tabular}

Mean values \pm Standard Errors are given. Marginal and Conditional R2 are provide in case of linear mixed models. Stat. Statistics of the test, Value Value of test statistics, $D f$ degrees of freedom. Significance codes: $P$ value $<0.001$ '***'; $P$ value $<0.01$ '**'; $P$ value $<0.05$ '*'. We provide marginal and conditional R2 for the analises at the individual level

therefore be accompanied by the measurement of other traits and metal concentrations in soils.

We detected a relatively wide variability in leaf traits, highlighting separate adaptive strategies in S. paradoxa populations. As expected, individuals growing on serpentine sites showed a greater polarisation of the typical features allowing survival in stressed environments, with traits responding to the central leaf economics spectrum (Wright et al. 2004), going toward a conservative economy. As a result, individuals in serpentine soils had substantially smaller leaves, with smaller SLA and (slightly) higher LDMC, and therefore slightly thicker leaves. These data are consistent with findings in Silene vulgaris (Moench) Garcke (Muszyńska et al. 2019), where metallicolous populations had thicker leaves than non-metallicolous ones. Even in crop plants, trace metal treatments have also been found to contribute to the appearance of xerophytic features in the leaf structure (i.e. small leaflets, thick lamina, thick upper epidermis, Shi and Cai 2009). Our results are consistent with the general concept that a low SLA is linked to a Stress-tolerant strategy, together with low rates of nutrient uptake, low growth rates and slow leaf turnover (Wright et al. 2004; Westoby and Wright 2006). Nevertheless, it should be noted that considering the multifaceted source of stress within serpentine contexts, this trait variation may be the combined result of different environmental factors acting simultaneously and not independently, as pointed out by Anacker et al. (2011).

Individuals of $S$. paradoxa grown in serpentine and non-serpentine sites showed a significant intraspecific trait variation in leaf traits. This was linked with the polarisation towards the S strategy of individuals from populations grown on serpentine sites. Particularly, those grown on serpentine sites showed a net S/SR strategy, while those grown on non-serpentine sites also showed an important $\mathrm{C}$ component. resulting in a $\mathrm{S} /$ CSR strategy. The significance of intraspecific trait variation in our model system is consistent with the findings of many authors, who have already shown that species might exhibit trait differences among populations, for example due to geographic clines corresponding with environmental gradients (see Aitken and Whitlock 2013) or differences in the ecology of hosting sites (Astuti et al. 2018). Here we should note that the approach proposed by Pierce et al. (2017) concerned the use of leaf traits to depict the CSR strategies among species across widely diverging biomes worldwide. Our case study however supports the idea that such an approach may be also used at the intraspecific level, as already shown by Astuti et al. (2018) in the case of Bellevalia webbiana Parl., showing significant intraspecific variation in CSR strategy in sites with different ecological constraints. Trait divergence under the selective pressures stemming from metalliferous soils has been documented in several other case studies from broad niche metallophytes (es. Anisopappus chinensis (L.) Hook. \& Arn. in tropical Africa from Lange et al. 2017) or facultative serpentinophytes (as in the already cited case study of Helianthus exilis from Sambatti and Rice 2007). This is in line with recent arguments that world-wide economics spectrum may not hold when working at smaller spatial or organisational scales (e.g. Niinemets 2015) and with the need to consider withinspecies economics spectrum in regional- to biome-level analyses. Similarly, intraspecific trait variation should be carefully considered in the study of global trends in plant adaptive strategies. 

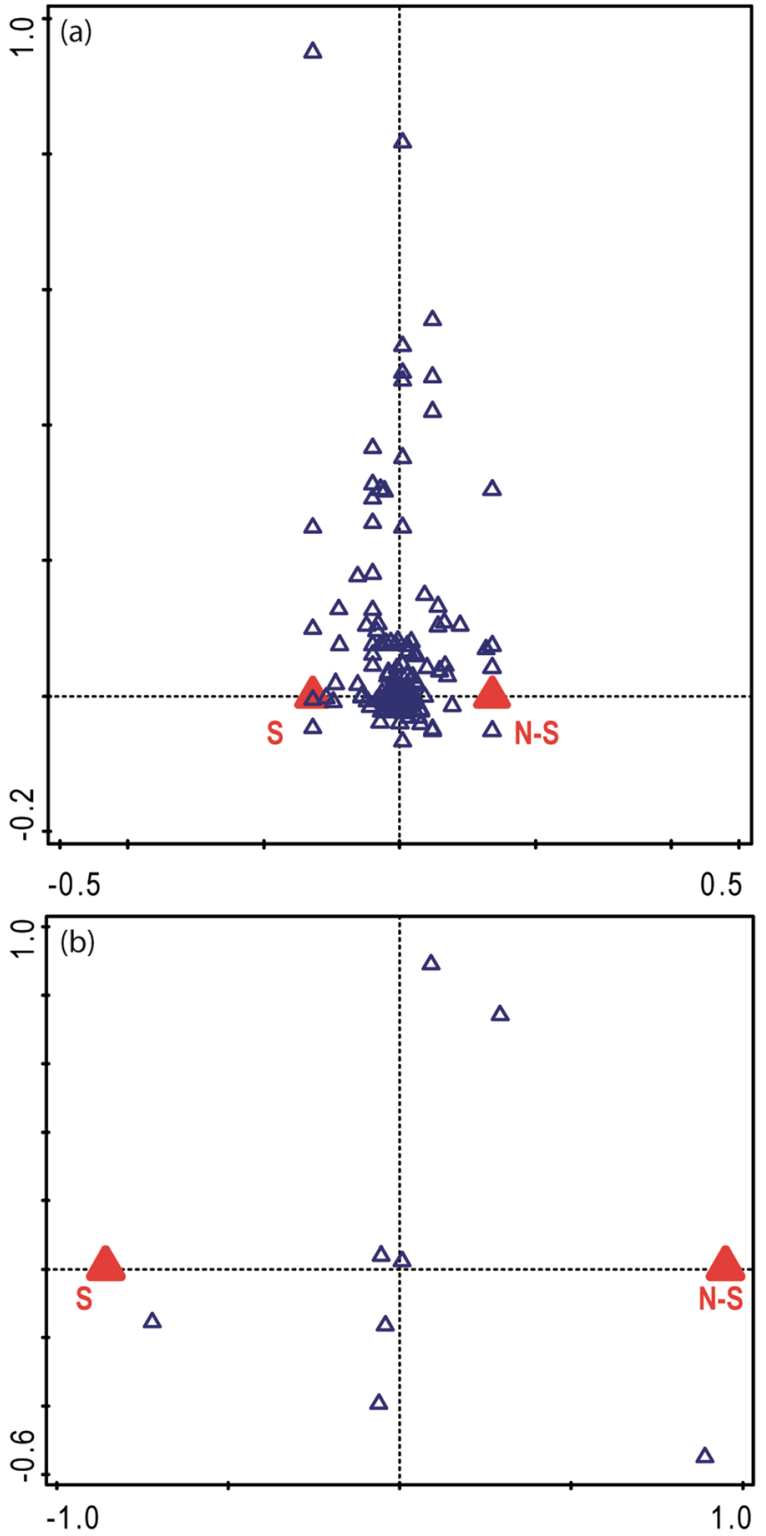

Fig. 6 Distribution of loci as detected by AFLP analyses according to Canonical Correspondence Analyses constrained on site soil type: $\mathrm{S}=$ serpentine sites; $\mathrm{N}-\mathrm{S}=$ non-serpentine sites. (a) Total loci, (pseudo-F $=2.3 ; \mathrm{P}$ value $<0.001$ ) and $(\mathbf{b})$ loci under selective pressure (pseudo- $\mathrm{F}=19 ; \mathrm{P}$ value $<0.001$ )

We recorded a medium-high genetic diversity for the populations from both soil types (serpentine and nonserpentine sites), with no significant differences among serpentine versus non-serpentine populations. These results are consistent with a previous study on another non-obligate serpentinophyte (Onosma echioides L., Boraginaceae, see Mengoni et al. 2006), but contrasted with the reduction in genetic diversity observed in several taxa from serpentine, or in general, stressful environments (Coppi et al. 2008; Deng et al. 2007; Nordal et al. 1999), including S. paradoxa populations found in mine tailings (Mengoni et al. 2001). Nevertheless, the lack of a specific genetic structure of the populations, with no clear separation among serpentine and non-serpentine populations obtained via AFLP analyses, is consistent with the results obtained on the same species with random amplified polymorphic DNA (Mengoni et al. 2000) and chloroplast microsatellite analyses (Mengoni et al. 2001). Our data reinforce the hypothesis that the adaptation to serpentine soils may emerge repeatedly from the genetic pool of the nonserpentine populations. It is not clear whether, as suggested in Sakaguchi et al. (2019) for Solidago virgaurea, divergence in serpentine ecotypes may be maintained in parapatry via prezygotic isolation through divergent flowering time (early flowering times of serpentine ecotypes). According to von Wettberg et al. (2014), many serpentine tolerant taxa may have evolved from taxa from other habitats also displaying stresstolerant traits, and (following Chapin et al. 1993) the taxa in which adaptation to serpentine soils is most likely to evolve, are those that already have stress tolerance. Moreover, again according to Chapin et al. 1993, the adaptations to stressful habitats may evolve rapidly with variation in very few genes, as also demonstrated in more recent case studies (see for example the case of two Howea Becc. palm species in Savolainen et al. 2006 or the case of divergence in Helianthus L. ecotypes in Andrew and Rieseberg 2013) Indeed there is large evidence for a repeated evolution of metal-tolerance in Silene L. genus, as well as the evolution of metaltolerant ecotypes, e.g. in the case of a copper ecotype within the S. burchelli complex in southern Africa, which falls into a gradient of morphological and anatomical modifications within this complex (Malaisse et al. 1983).

Notwithstanding the lack of quantitative differences, the CCA and the ISA highlighted the presence of substantial differences in the distribution of total and outlier loci among populations from serpentine and nonserpentine sites, allowing the identification of a number of total and outlier loci typical of the serpentine populations. Similar results were obtained in the facultative hyperaccumulator Alyssum serpyllifolium Desf. (Brassicaceae), where 34 out of 374 AFLP loci had a potential adaptive value related to $\mathrm{Ni}$ hyperaccumulation and serpentine tolerance (Quintela- 
Sabarıs et al. 2017). Although it is not possible at present to propose a mechanistic basis for these results, our data provide evidence that the observed intraspecific variation in functional traits could stem from the DNA marker-trait associations. Indeed, AFLP restriction sites in plants are often located within gene sequences, or linked to multiple major or minor genes or associated to quantitative trait loci (QTLs), including some of the traits considered in this research, such as LA and SLA (Caballero et al. 2013; Medrano et al. 2014; Scalfi et al. 2004; Bratteler et al. 2006) indicated that Ni tolerance and leaf succulence of $S$. vulgaris were associated with the selection of 15 major and 8 minor QTLs, providing valuable insights for the understanding of the genetic architecture of serpentine adaptation.

As reported for other biological systems, we cannot exclude that the presence of high concentrations of trace elements could produce DNA mutations due to a possible increase in random mutation rate (Coppi et al. 2018; Mengoni et al. 2001) or to DNA methylation (Labra et al. 2004). In our case, the use of a methylationsensitive restriction enzyme (EcoRI), may have mixed up the effects of methylation changes. These issues suggest new research possibilities on the role of methylation in adaptation to stressful environments. As well, the use of advanced genomics studies, such as Transcriptomics and Next-Generation sequencing, converging in the field of "serpentinomics" (sensu Wright and von Wettberg 2009), can be considered pivotal in unravelling the mechanistic and genetic basis of the complexities of tolerance of and adaptation to serpentine soils, thus providing more insight in the system we propose within this study.

In conclusion, our data highlighted the presence of a not negligible intraspecific trait variation in populations of $S$. paradoxa growing in serpentine vs. non-serpentine sites, coupled with a valuable polarisation toward the $\mathrm{S}$ strategy in the CSR context of serpentine populations. The adaptive trade-off in $S$. paradoxa could be linked to the selection of specific outlier loci, revealing a genetic structure of the species that should be studied in greater detail. Further studies, with the use of more in deep genomics approaches and also including other functional traits more specific of trace metal stress, are needed to disentangle the effective role of these DNA regions under selective pressure in the emergence of adaptive strategies, unravelling the genetic control of ecologically important traits.
Supplementary Information The online version contains supplementary material available at https://doi.org/10.1007/s11104020-04780-1.

Acknowledgements We wish to thank Prof. Federico Selvi (Department of Agriculture, Food, Environment and Forestry, DAGRI, University of Florence) for his suggestions and comments that greatly helped in improving our manuscript. We also wish to thank two Anonymous Reviewers, whose suggestions greatly improved our manuscript.

Author contributions LLaz and AC conceived the ideas and designed the methodology. LLaz, AC, DV, LLas and IC collected the data. DC, LLaz, AC and IC analysed the data. LLaz, IC, CG, $\mathrm{NB}$ and AC led the writing of the manuscript. All authors contributed critically to the drafts and gave final approval for publication.

Funding Open access funding provided by Università degli Studi di Firenze within the CRUI-CARE Agreement.

Compliance with ethical standards

Conflict of interest The authors declare no competing interests.

Open Access This article is licensed under a Creative Commons Attribution 4.0 International License, which permits use, sharing, adaptation, distribution and reproduction in any medium or format, as long as you give appropriate credit to the original author(s) and the source, provide a link to the Creative Commons licence, and indicate if changes were made. The images or other third party material in this article are included in the article's Creative Commons licence, unless indicated otherwise in a credit line to the material. If material is not included in the article's Creative Commons licence and your intended use is not permitted by statutory regulation or exceeds the permitted use, you will need to obtain permission directly from the copyright holder. To view a copy of this licence, visit http://creativecommons.org/licenses/by/4.0/.

\section{References}

Aitken SN, Whitlock MC (2013) Assisted gene flow to facilitate local adaptation to climate change. Annu Rev Ecol Evol Syst 44:367-388. https://doi.org/10.1146/annurev-ecolsys110512-135747

Anacker B, Rajakaruna N, Ackerly D, Harrison S, Keeley J, Vasey M (2011) Ecological strategies in California chaparral: interacting effects of soils, climate, and fire on specific leaf area. Plant Ecol Divers 4(2-3): 179-188

Andrew RL, Rieseberg LH (2013) Divergenceis focused on few genomic regions early in speciation: incipient speciation ofsunflower ecotypes. Evolution 67:2468-2482. https://doi. org/10.1111/evo.12106 
Arnetoli M, Vooijs R, Gonnelli C, Gabbrielli R, Verkleij JAC, Schat H (2008) High-level $\mathrm{Zn}$ and Cd tolerance in Silene paradoxa $\mathrm{L}$. from a moderately $\mathrm{Cd}$ - and $\mathrm{Zn}$-contaminated copper mine tailing. Environ Pollut 156:380-386. https://doi. org/10.1016/j.envpol.2008.01.044

Asemaneh T, Ghaderian SM, Baker AJM (2007) Responses to $\mathrm{Mg} / \mathrm{Ca}$ balance in an Iranian serpentine endemic plant, Cleome heratensis (Capparaceae), and a related nonserpentine species, C. foliolosa. Plant Soil 293:49-59. doi: https://doi.org/10.1007/s11104-006-9147-7

Astuti G, Ciccarelli D, Roma-Marzio F, Trinco A, Peruzzi L (2018) Narrow endemic species Bellevalia webbiana shows significant intraspecific variation in tertiary CSR strategy. Plant Biosyst 153:12-18. https://doi.org/10.1080 $/ 11263504.2018 .1435576$

Bates D, Mächler M, Bolker B, Walker S (2015) Fitting linear mixed-effects models using lme4. J Stat Softw 67(1):1-48. https://doi.org/10.18637/jss.v067.i01

Beaumont MA, Balding DJ (2004) Identifying adaptive genetic divergence among populations from genome scans. Mol Ecol 13:969-980. https://doi.org/10.1111/j.1365-294 X.2004.02125.x

Beaumont MA, Nichols RA (1996) Evaluating loci for use in the genetic analysis of population structure. Proc R Soc Lond B Biol Sci 263:1619-1626. https://doi.org/10.1098 /rspb.1996.0237

Bettarini I, Colzi I, Coppi A, Falsini S, Echevarria G, Pazzagli L, Selvi F, Gonnelli C (2019) Unravelling soil and plant metal relationships in Albanian nickel hyperaccumulators in the genus Odontarrhena (syn. Alyssum sect. Odontarrhena, Brassicaceae). Plant Soil 440:135-149. https://doi. org/10.1007/s11104-019-04077-y

Box GEP, Cox DR (1964) An analysis of transformations (with discussion). J R Stat Soc Series B 26:211-252

Bragg JG, Supple MA, Andrew RL, Borevitz JO (2015) Genomic variation across landscapes: insights and applications. New Phytol 207:953-967

Bratteler M, Lexer C, Widmer A (2006) Genetic architecture of traits associated with serpentine adaptation of Silene vulgaris. J Evol Biol 19:1149-1156. https://doi.org/10.1111/j.14209101.2006.01090.x

Brooks RR (1987) Serpentine and its vegetation: a multidisciplinary approach. Inc. 9999 S.W. Wilshire. Dioscorides Press, Portland

Burr TL (2000) Quasi-equilibrium theory for the distribution of rare alleles in a subdivided population: justification and implications. Theor Popul Biol 57:297-306. https://doi. org/10.1006/tpbi.2000.1453

Burrell AM, Hawkins AK, Pepper AE (2012) Genetic analyses of nickel tolerance in a North American serpentine endemic plant, Caulanthus amplexicaulis var. barbarae (Brassicaceae). Am J Bot 99(11):1875-1883. https://doi. org/10.3732/ajb.1200382

Caballero A, García-Pereira MJ, Quesada H (2013) Genomic distribution of AFLP markers relative to gene locations for different eukaryotic species. Genom 14:528. https://doi. org/10.1186/1471-2164-14-528

Chapin FS III, Autumn K, Pugnaire F (1993) Evolution of suites of traits in response to environmental stress. Am Nat 142:S78S92
Chiarucci A, Foggi B, Selvi F (1995) Garigue plant communities of ultramafic out-crops of Tuscany (Central Italy). Webbia 49: 179-192. https://doi.org/10.1080/00837792.1995.10670581

Colzi I, Pignattelli S, Giorni E, Papini A, Gonnelli C (2015) Linking root traits to copper exclusion mechanisms in Silene paradoxa L. (Caryophyllaceae). Plant Soil 390:1-15. https://doi.org/10.1007/s11104-014-2375-3

Coppi A, Cecchi L, Mengoni A, Phustahija F, Tomović G, Selvi F (2014) Low genetic diversity and contrasting patterns of differentiation in the two monotypic genera Halacsya and Paramoltkia (Boraginaceae) endemic to the Balkan serpentines. Flora 209:5-14. https://doi.org/10.1016/j. flora.2013.11.002

Coppi A, Lastrucci L, Cappelletti D, Cerri M, Ferranti F, Ferri V, Foggi B, Gigante D, Venanzoni R, Viciani D, Selvaggi R, Reale L (2018) AFLP approach reveals variability in Phragmites australis: implications for its die-back and evidence for genotoxic effects. Front Plant Sci 9:386. https://doi. org/10.3389/fpls.2018.00386

Coppi A, Mengoni A, Selvi F (2008) AFLP fingerprinting of Anchusa (Boraginaceae) in the Corso-Sardinian system: Genetic diversity, population differentiation and conservation priorities in an insular endemic group threatened with extinction. Biol Conserv 141:2000-2011. https://doi. org/10.1016/j.biocon.2008.05.015

Courbot M, Willems G, Motte P, Arvidsson S, Roosens N, Saumitou-Laprade P, Verbruggen N (2007) A major quantitative trait locus for cadmium tolerance in Arabidopsis halleri colocalizes with HMA4, a gene encoding a heavy metal ATPase. Plant Physiol 144(2):1052-1065. https://doi. org/10.1104/pp.106.095133

Deng J, Liao B, Ye M, Deng D, Lan C, Shu W (2007) The effects of heavy metal pollution on genetic diversity in zinc/ cadmium hyperaccumulator Sedum alfredii populations. Plant Soil 297:83-89. https://doi.org/10.1007/s11104-0079322-5

Deniau AX, Pieper B, Ten Bookum WM, Lindhout P, Aarts MGM, Schat H (2006) QTL analysis of cadmium and zinc accumulation in the heavy metal hyperaccumulator Thlaspi caerulescens. Theor Appl Genet 113(5):907-920. https://doi. org/10.1007/s00122-006-0350-y

Diniz-Filho JA, Soares TN, Lima JS, Dobrovolski R, Landeiro VL, de Campos Telles MP, Bini LM (2013) Mantel test in population genetics. Genet Mol Biol 36(4):475-485. https://doi.org/10.1590/S1415-47572013000400002

Doyle JJ, Doyle JL (1990) Isolation of plant DNA from fresh tissue. Focus 12:13-15

Dufrêne M, Legendre P (1997) Species assemblages and indicator species: the need for a flexible asymmetrical approach. Ecol Monogr 67(3):345-366. https://doi.org/10.2307/2963459

Excoffier L, Smouse PE, Quattro M (1992) Analysis of molecular variance inferred from metric distances among DNA haplotypes, application to human mitochondrial DNA restriction data. Genet 131:479-491

Ghasemi R, Chavoshi ZZ, Boyd RS, Rajakaruna N (2015) Calcium: magnesium ratio affects environmental stress sensitivity in the serpentine-endemic Alyssum inflatum (Brassicaceae). Aust J Bot 63(2):39-46. https://doi. org/10.1071/BT14235

Gonnelli C, Galardi F, Gabbrielli R (2001) Nickel and copper tolerance and toxicity in three Tuscan populations of Silene 
paradoxa. Physiol Plant 113(4):507-514. https://doi. org/10.1034/j.1399-3054.2001.1130409.x

Gonnelli C, Renella G (2012) Chromium and Nickel. In: Alloway BJ (ed) Heavy Metals in Soils. Springer, Dordrecht

Grime JP (1977) Evidence for the existence of three primary strategies in plants and its relevance to ecological and evolutionary theory. Am Nat 111:1169. https://doi.org/10.1086 $/ 283244$

Grime JP, Pierce S (2012) The evolutionary strategies that shape ecosystems. Wiley-Blackwell, Oxford

Hamilton NE, Ferry M (2018) ggtern: ternary diagrams using ggplot2. J Stat Softw 87(3):1-17. https://doi.org/10.18637 jjs.v087.c03

Harrison S, Rajakaruna N (2011) Serpentine: The evolution and ecology of a model system. University of California Press, Berkeley

Hothorn T, Bretz F, Westfall P (2008) Simultaneous inference in general parametric models. Biom J 50(3):346-363. https://doi.org/10.1002/bimj.200810425

Kazakou E, Dimitrakopoulos PG, Baker AJM, Reeves RD, Troumbis AY (2008) Hypotheses, mechanisms and tradeoffs of tolerance and adaptation to serpentine soils: from species to ecosystem level. Biol Rev 83(4):495-508. https://doi.org/10.1111/j.1469-185X.2008.00051.x

Kruckeberg AR (1986) The birth and spread of a plant population. Am Midl Nat 116(2):403-410

Kuznetsova A, Brockhoff PB, Christensen RHB (2017) lmerTest Package: tests in linear mixed effects models. J Stat Softw 82(13):1-26. https://doi.org/10.18637/jss.v082.i13

Labra M, Grassi F, Imazio S, Di Fabio T, Citterio S, Sgorbati S, Agradi E (2004) Genetic and DNA-methylation changes induced by potassium dichromate in Brassica napus $\mathrm{L}$. Chemosphere 54(8):1049-1058

Lange B, Faucon MP, Delhaye G, Hamiti N, Meerts P (2017) Functional traits of a facultative metallophyte from tropical Africa: population variation and plasticity in response to cobalt. Environ Exper Bot 136:1-8

Lefcheck JS (2016) piecewiseSEM: Piecewise structural equation modeling in R for ecology, evolution, and systematics. Methods Ecol Evol 7(5):573-579. DOI:https://doi. org/10.1111/2041-210X.12512

Lefèbvre C, Vernet P (1990) Microevolutionary processes on contaminated deposits. In: Shaw AJ (ed) Heavy metal tolerance in plants: Evolutionary aspects. C.R.C. Press Inc., Boca Raton, pp 285-300

Madhok OP, Walker RB (1969) Magnesium nutrition of two species of sunflower. Plant Physiol 44:1016-1022. doi: https://doi.org/10.1104/pp.44.7.1016

Malaisse F, Colonval-Elenkov E, Brooks RR (1983) The impact of copper and cobalt orebodies upon the evolution of some plant species from Upper Shaba, Zaïre. P1. Syst Evol 142: 207-221

Manly BFJ (1986) Multivariate statistical methods: a primer. Chapman \& Hall, London

Marschner H (1995) Mineral nutrition of higher plants. Academic, London

Martellini F, Giorni E, Colzi I, Luti S, Meerts P, Pazzagli L, Gonnelli C (2014) Can adaptation to metalliferous environments affect plant response tobiotic stress? Insight from Silene paradoxa L. and phytoalexins. Environ Exp Bot 108:38-46. https://doi.org/10.1016/j. envexpbot.2013.11.014

Medrano M, Herrera CM, Bazaga P (2014) Epigenetic variation predicts regional and local intraspecific functional diversity in a perennial herb. Mol Ecol 23(20):4926-4938. https://doi. org $/ 10.1111 / \mathrm{mec} .12911$

Mengoni A, Barabesi C, Gonnelli C, Galardi F, Gabbrielli R, Bazzicalupo M (2001) Genetic diversity of heavy metaltolerant populations in Silene paradoxa L. (Caryophyllaceae): a chloroplast microsatellite analysis. Mol Ecol 10:1909-1916. https://doi.org/10.1046/j.0962-1083.2001.01336.x

Mengoni A, Gonnelli C, Galardi F, Gabbrielli R, Bazzicalupo M (2000) Genetic diversity and heavy metal tolerance in populations of Silene paradoxa L. (Caryophyllaceae): a random amplified polymorphic DNA analysis. Mol Ecol 9:13191324. doi:https://doi.org/10.1046/j.1365-294x.2000.01011.x

Mengoni A, Selvi F, Cusimano N, Galardi F, Gonnelli C (2006) Genetic diversity inferred from AFLP fingerprinting in populations of Onosma echioides (Boraginaceae) from serpentine and calcareous soils. Plant Biosyst 140(2):211-219

Moore AJ, Merges D, Kadereit JW (2013) The origin of the serpentine endemic Minuartia laricifolia subsp. ophiolitica by vicariance and competitive exclusion. Molecular Ecology 22(8):2218-2231. https://doi.org/10.1111/mec.12266

Muszyńska E, Labudda M, Różańska E, Hanus-Fajerska E, Koszelnik-Leszek A (2019) Structural, physiological and genetic diversification of Silene vulgaris ecotypes from heavy metal-contaminated areas and their synchronous in vitro cultivation. Planta 249:1761-1778. https://doi. org/10.1007/s00425-019-03123-4

Nei M (1987) Molecular Evolutionary Genetics. Columbia University Press, New York

Nakagawa S, Schielzeth H (2013) A general and simple method for obtaining R2 from generalized linear mixed-effects models. Methods Ecol Evol 4(2):133-142

Niinemets Ü (2015) Is there a species spectrum within the world-wide leaf economics spectrum? Major variations in leaf functional traits in the Mediterranean sclerophyll Quercus ilex. New Phytol 205(1):79-96. https://doi.org/10.1111/nph.13001

Nordal I, Haraldsen KB, Ergon A, Eriksen AB (1999) Copper resistance and genetic diversity in Lychnis alpina (Caryophyllaceae) populations on mining sites. Folia Geobot 34:471-481. https://doi.org/10.1007/BF02914923

Perez-Harguindeguy N, Diaz S, Garnier E et al (2013) New handbook for standardised measurement of plant functional traits worldwide. Aust J Bot 61(3):167-234. https://doi. org/10.1071/BT12225

Pierce S, Negreiros D, Cerabolini BEL et al (2017) A global method for calculating plant CSR ecological strategies applied across biomes world-wide. Funct Ecol 31:444- 457. https://doi.org/10.1111/1365-2435.12722

Pignattelli S, Colzi I, Buccianti A, Cattani I, Beone GM, Schat H, Gonnelli C (2013) A multielement analysis of $\mathrm{Cu}$ induced changes in the mineral profiles of $\mathrm{Cu}$ sensitive and tolerant populations of Silene paradoxa L. Environ Exp Bot 96:20 27. https://doi.org/10.1016/j.envexpbot.2013.09.006 
Pignatti S (1997) Flora D'italia, 1. Agricole, Bologne

Pollard AJ, Reeves RD, Baker AJ (2014) Facultative hyperaccumulation of heavy metals and metalloids. Plant Sci 217:8-17

Pritchard JK, Stephens M, Donnelly P (2000) Inference of population structure using multilocus genotype data. Genetics 155(2):945-959

Quintela-Sabarís C, Marchand L, Smith JAC, Kidd PS (2017) Using AFLP genome scanning to explore serpentine adaptation and nickel hyperaccumulation in Alyssum serpyllifolium. Plant Soil 416:391-408. https://doi.org/10.1007/s11104-017-3224-y

Quintela-Sabarís C, Vendramin GG, Castro-Fernández D, Fraga MI (2010) Chloroplast microsatellites reveal that metallicolous populations of the Mediterranean shrub Cistus ladanifer L have multiple origins. Plant Soil 334: 161-174. https://doi.org/10.1007/s11104-010-0368-4

Rajakaruna N (2018) Lessons on evolution from the study of edaphic specialization. Bot Rev 84:39-78. https://doi. org/10.1007/s12229-017-9193-2

Rajakaruna N, Boyd RS (2009) Advances in serpentine geoecology: a retrospective. Northeast Nat 16:1-7. https://doi.org/10.1656/045.016.0501

Rannala B (1996) The sampling theory of neutral alleles in an island population of fluctuating size. Theor Popul Biol 50: 91-104. https://doi.org/10.1006/tpbi.1996.0024

Rannala B, Hartigan JA (1996) Estimating gene flow in island populations. Genet Res 67:147-158. https://doi.org/10.1017 /S0016672300033607

Saitou N, Nei M (1987) The Neighbour-Joining method, a new method for reconstructing phylogenetic trees. Mol Biol Evol 4:406-425. https://doi.org/10.1093/oxfordjournals.molbev. a040454

Sakaguchi S, Horie K, Ishikawa N, Nagano AJ, Yasugi M, Kudoh H, Ito M (2017) Simultaneous evaluation of the effects of geographic, environmental and temporal isolation in ecotypic populations of Solidago virgaurea. New Phytol 216:12681280. doi:https://doi.org/10.1111/nph.14744

Sakaguchi S, Horie K, Ishikawa N, Nishio S, Worth JR, Fukushima K, Yamasaki M, Ito M (2019) Maintenance of soil ecotypes of Solidago virgaurea in close parapatry via divergent flowering time and selection against immigrants. J Ecol 107(1):418-435

Sambatti JBM, Rice KJ (2007) Functional ecology of ecotypic differentiation in the Californian serpentine sunflower (Helianthus exilis). New Phytol 175:107-119. doi: https://doi.org/10.1111/j.1469-8137.2007.02068.x

Savolainen V, Anstett M-C, Lexer C, Hutton I, Clarkson JJ, Norup MV, Powell MP, Springate D, Salamin N, Baker WJ (2006) Sympatric speciation in palms on an oceanic island. Nature 441:210-213

Scalfi M, Troggio M, Piovani P, Leonardi S, Magnaschi G, Vendramin GG, Menozzi P (2004) A RAPD, AFLP and SSR linkage map, and QTL analysis in European beech (Fagus sylvatica L.). Theor Appl Genet 108:433-441. https://doi.org/10.1007/s00122-003-1583-7

Schneider CA, Rasband WS, Eliceiri KW (2012) NIH Image to ImageJ: 25 years of image analysis. Nat Methods 9(7):671675. https://doi.org/10.1038/nmeth.2089
Schneider S, Rosselli D, Excoffier L (2000) Arlequin: a software for population genetics data analysis, version 2.000. University of Geneva, Geneva

Selby JP, Willis JH (2018) Major QTL controls adaptation to serpentine soils in Mimulus guttatus. Mol Ecol 27:50735087. https://doi.org/10.1111/mec. 14922

Selvi F (2007) Diversity, geographic variation and conservationof the serpentine flora of Tuscany (Italy). Biodivers Conserv 16: 1423-1439. https://doi.org/10.1007/s10531-006-6931-x

Shi G, Cai Q (2009) Leaf plasticity in peanut (Arachis hypogaea L.) in response to heavy metal stress. Environ Exp Bot 67(1): 112-117. https://doi.org/10.1016/j.envexpbot.2009.02.009

Sianta SA, Kay KM (2019) Adaptation and divergence in edaphic specialists and generalists: serpentine soil endemics in the California flora occur in barer serpentine habitats with lower soil calcium levels than serpentine tolerators. Am J Bot 106(5):690-703

Slatkin M (1995) A measure of population subdivision based on microsatellite allele frequencies. Genetics 139:457-462

Stojanova B, Šurinová M, Zeisek V, Münzbergová Z, Pánková H (2020) Low genetic differentiation despite high fragmentation in the endemic serpentinophyte Minuartia smejkalii (M. verna agg., Caryophyllaceae) revealed by RADSeq SNP markers. Conserv Genet 21:187-198

Suding KN, Lavorel S, Chapin Iii FS et al (2008) Scaling environmental change through the community-level: a trait-based responseand-effect framework for plants. Glob Chang Biol 14(5):11251140. https://doi.org/10.1111/j.1365-2486.2008.01557.x

Ter Braak CJF, Smilauer P (2012) Canoco reference manual and user's guide: software for ordination, version 5.0. Microcomputer Power, Ithaca

Tibbetts RA, Smith JAC (1993) Vacuolar accumulation of calcium and its interaction with magnesium availability. In: Baker AJM, Proctor J, Reeves RD (eds) The vegetation of ultramafic (serpentine) soils: proceedings of the first international conference on serpentine ecology. Intercept, Andover, pp 367-373

Turner TL, Bourne EC, von Wettberg EJ, Hu TT, Nuzhdin SV (2010) Population resequencing reveals local adaptation of Arabidopsis lyrata to serpentine soils. Nat Gen 42:260-263

Violle C, Navas M-L, Vile D, Kazakou E, Fortunel C, Hummel I, Garnier E (2007) Let the concept of trait be functional! Oikos 116:882-892. https://doi.org/10.1111/j.00301299.2007.15559.x

Von Wettberg EJ, Ray-Mukherjee J, D’Adesky N, Nesbeth D, Sistla S (2014) The evolutionary ecology and genetics of stress resistance syndrome (SRS) traits: revisiting Chapin, Autumn and Pugnaire (1993). In: Rajakaruna N, Boyd RS, Harris T (eds) Plant ecology and evolution in harsh environments. pp 201-226

Vos P, Hogers R, Bleeker M et al (1995) AFLP: a new technique for DNA fingerprinting. Nucleic Acids Res 23(21):44074414. https://doi.org/10.1093/nar/23.21.4407

Wallace A, Jones MB, Alexander GV (1982) Mineral composition of native woody plants growing on serpentine soil in California. Soil Sci 134:42-44. doi:https://doi.org/10.1097 /00010694-198207000-00008

Westoby M, Wright IJ (2006) Land-plant ecology on the basis of functional traits. Trends Ecol Evol 21(5):261-268 
Wickham H (2016) ggplot2: elegant graphics for data analysis. Springer-Verlag, New York

Willems G, Drager DB, Courbot M, Gode C, Verbruggen N, Saumitou-Laprade $\mathrm{P}$ (2007) The genetic basis of zinc tolerance in the Metallophyte Arabidopsis halleri ssp. halleri (Brassicaceae): Ananalysis of quantitative trait loci. Genetics 176(1):659-674. https://doi.org/10.1534/genetics.106.064485

Wright IJ, Reich PB, Westoby M et al (2004) The worldwide leaf economics spectrum. Nature 428(6985):821. https://doi. org/10.1038/nature02403

Wright JW, von Wettberg E (2009) “Serpentinomics" - An emerging new field of study. Northeastern Nat 16(sp5):285-296
Yang AH, Dick CW, Yao XH, Huang HW (2016) Impacts of biogeographic history and marginal population genetics on species range limits: a case study of Liriodendron chinense. Sci Rep 6:25632. https://doi.org/10.1038/srep25632

Yang MH, Fu YB (2017) AveDissR: An R function for assessing genetic distinctness and genetic redundancy. Appl Plant Sci 5(7):pps.1700018. https://doi.org/10.3732/apps.1700018

Publisher's Note Springer Nature remains neutral with regard to jurisdictional claims in published maps and institutional affiliations. 